\title{
Do Benign Mass Lesions in the Superficial Lobe of Parotid Gland Influence Landmark-Based Search for Facial Nerve Trunk At Surgery?
}

\author{
Parotis Bezinin Yüzeyel Lobundaki lyi Huylu Kitle Lezyonları Fasiyal Sinir \\ Kordonu Konumuma Dayalı Cerrahi Araştırmaları Etkiler mi?
}

\author{
Subhadip SARDAR $\odot$, Mainak DUTTA $\odot$, Sirshak DUTTA $\odot$, Saumik DAS $\odot$, Ramanuj SINHA $\odot$
}

Ethics Committee Approval: This study approved by the Institutional Ethics Committee of Medical College Kolkata, 18 November 2017, 661/11-2017.

Conflict of interest: The authors declare that they have no conflict of interest.

Funding: None.

Informed Consent: Informed consent was taken from the participants of the study.
Cite as: Sardar S, Dutta M, Dutta S, Das S, Sinha R. Do benign mass lesions in the superficial lobe of parotid gland influence landmark-based search for facial nerve trunk at surgery?. Medeni Med J. 2021;36:36-43.

\begin{abstract}
Objective: To assess the influence of benign mass lesions in the superficial lobe of parotid on the known anatomic landmarks for identifying the facial nerve trunk.

Method: Patients with unilateral biopsy-proven benign mass lesions in the superficial parotid were selected for this observational study. During superficial/partial superficial parotidectomy, distance of the facial nerve trunk from each landmark was assessed using spring calliper and correlated with the lesion's volume (measured from the pre-operative imaging). At least two identifiers among tragal pointer (TP), posterior belly of digastric muscle (PBDM) and tympanomastoid suture (TMS) were considered.

Results: The study involved 32 patients. The lesions mostly involved the parotid tail (50\%) and pretragal region (34.3\%), and constituted of pleomorphic adenoma ( 66\%) and Warthin's tumor ( 9\%), the rest being various cysts and hamartomas. TP was universally uncovered, while PBDM and TMS were exposed in 26 and 25 patients, respectively. Average distances between the facial nerve trunk and TP, PBDM and TMS were $12.79 \mathrm{~mm}(S D=2.33), 9.78 \mathrm{~mm}(S D=1.21)$ and $7.58 \mathrm{~mm}(S D=1.33)$, respectively. Correlation coefficients between the lesion's volume and the distance of facial nerve from a given landmark were $-0.11,0.04$ and -0.16 for TP, PBDM and TMS, respectively.

Conclusions: TP was the most easily available landmark on surgical dissection, while PBDM was the most consistent and the least variable when volumetric data of the benign mass lesions in the superficial lobe of parotid were considered as a factor influencing the distance from the facial nerve trunk.
\end{abstract}

Keywords: Tragal pointer, posterior belly of digastric muscle, tympanomastoid suture, pleomorphic salivary adenoma, Warthin's tumor, superficial parotidectomy, partial superficial parotidectomy

öz

Amaç: Parotis bezinin yüzeyel lobundaki iyi huylu kitle lezyonların, fasiyal sinir kordonunu belirlemek için bilinen anatomik konumu üzerindeki etkisini değerlendirmek.

Yöntem: Bu gözlemsel calıșma için tek taraflı biyopsi ile kanıtlanmıș, yüzeyel parotis bezinde iyi huylu kitle lezyonları olan hastalar seçilmiştir. Yüzeyel / kısmi yüzeyel parotidektomi sırasında, fasiyal sinir kordonunun her bir noktaya uzaklığı yaylı kaliperler ve ölçek kullanılarak değerlendirilmis ve lezyonun hacmi ile ilișkilendirilmistir (ameliyat öncesi görüntüleme ile ölcülmüstür). Tragal işaretçi (TP), digastrik kasın arka göbeği (PBDM) ve timpanomastoid sütür (TMS) arasında en az iki tanımlayıcı değerlendirilmiştir.

Bulgular: Calıșma 32 hastayı içermektedir. Lezyonlar çŏ̌unlukla parotis kuyruğu (\%50) ve pretragal bölgeyi $(\% 34,3)$ içermekte, pleomorfik adenom ( \%66) ve Warthin tümöründen ( \%9) meydana gelmekte, geri kalanı ise çeşitli kistlerden ve hamartomlardan oluşmaktaydı. TP evrensel olarak ortaya cıkarılırken, PBDM ve TMS sırasıyla 26 ile 25 hastada acı̆ga cıkarılmıstır. Fasiyal sinir gövdesi ile TP, PBDM ve TMS arasındaki ortalama mesafeler sırasıyla $12.79 \mathrm{~mm}(\mathrm{sd}=2.33)$, $9.78 \mathrm{~mm}(s d=1.21)$ ve $7.58 \mathrm{~mm}(s d=1.33)$ bulunmuştur. Lezyon hacmi ile fasiyal sinirin belirli bir noktadan uzaklığı arasındaki korelasyon katsayısı TP, PBDM ve TMS için sırasıyla, $-0.11,0.04$ ve - 0.16 olarak hesaplanmiştır.

Sonuç: TP cerrahi diseksiyonda en kolay ulaşılabilir dönüm noktası iken, parotis bezinin yüzeyel Iobundaki iyi huylu kitle lezyonlarının hacimsel verileri düşünüldügünde fasiyal sinir kordonundan uzaklığı etkileyen bir faktör olarak PBDM, en tutarlı ve en az değişken olarak belirlenmiştir.

Anahtar kelimeler: Tragal işaretçi, digastrik kasın arka göbeği, timpanomastoid sütür, pleomorfik tükürük adenomu, Warthin tümörü, yüzeyel parotidektomi, kısmi yüzeyel parotidektomi
Received: 20 December 2020

Accepted: 28 February 2021

Online First: 26 March 2021

Corresponding Author: S. Das

ORCID: 0000-0002-0213-4411 North Bengal Medical College and Hospital, Department of OtorhinolaryngologyHead and Neck Surgery, West Bengal, India

saumikdas65@gmail.com

\section{S. Sardar}

ORCID: 0000-0003-0975-3028

R. G. Kar Medical College and Hospital, Department of Otorhinolaryngology and Head-Neck Surgery, West Bengal, India

M. Dutta

ORCID: 0000-0003-3977-3230

R. Sinha

ORCID: 0000-0001-7215-4533

Kolkata Medical College and Hospital, Department of Otorhinolaryngology Head and neck Surgery, West Bengal, India

S. Dutta ORCID: 0000-0002-1688-9161

Raigunj Government Medical College and Hospital,

Department of OtorhinolaryngologyHead and neck Surgery, West Bengal, India 
S. Sardar et al., Do Benign Mass Lesions in the Superficial Lobe of Parotid Gland Influence Landmark-Based Search for Facial Nerve Trunk At Surgery?

\section{INTRODUCTION}

The impetus of this study was to search for a reliable and accurate landmark for locating the extratemporal facial nerve trunk in patients undergoing surgery for the parotid gland when its superficial lobe harbored a benign mass lesion of a given volume.

The parotid gland is divided anatomically into superficial and deep lobes by the retromandibular vein, and surgically by the intraparotid facial nerve $^{1}$. The facial nerve runs superficial to the retromandibular vein in the faciovenous plane of Patey for about $1 \mathrm{~cm}$, and then divides into an upper temporofacial and lower cervicofacial ram$u^{2}$. Identifying the facial nerve branches is a key step at parotid surgery, that becomes more challenging when their course gets distorted by mass lesions involving the gland. Such lesions are mostly benign, and they generally involve the superficial lobe. Therefore, during superficial or partial superficial parotidectomy, there is always a practical chance of post-operative facial paresis with branches of the lower trunk such as the marginal mandibular being more prone to get injured $^{3,4}$. There are multiple factors that can prevent or minimize this potentially avoidable complication, like meticulous dissection through the parotid tissue, using a nerve monitor, proper hemostasis, avoiding excessive traction, and most importantly, to locate the facial nerve trunk and its branches at the appropriate time of surgery. Successful delineation of the facial nerve trunk is dependent upon uncovering its landmarks which might get distorted in diseased conditions making the task relatively difficult.

The present study deals with identification of the reliable landmarks related to the surgical anatomy of facial nerve trunk during superficial or partial superficial parotidectomy so that the extent of deviation of these landmarks under diseased conditions can be realized and predicted for future surgeries so as to obtain a better post-operative outcome.

\section{MATERIALS and METHOD}

This observational study was conducted between January 2018 and June 2019 in the department of Otorhinolaryngology and Head-Neck Surgery in a tertiary-care teaching institution of eastern India. Patients, irrespective of sex, with unilateral biopsy-proven benign mass lesions involving the superficial lobe of parotid, and planned for superficial or partial superficial parotidectomy, were selected for the study. Patients with co-existent facial paresis, associated or isolated deep lobe involvement, inability to successfully uncover more than one selected landmark for the facial nerve (see below) at surgery, malignant neoplasms, and having history of radiation exposure and prior parotid surgery were excluded. Patients were also excluded if the histopathology turned out to be malignant for neoplasms that were previously diagnosed as benign on fine needle aspiration cytology (FNAC).

In the setting of a benign mass lesion involving the superficial lobe of parotid, this study aims to find out: a) accuracy of the different known landmarks in identifying the facial nerve trunk during superficial/partial superficial parotidectomy through evaluation of their distance from each other [using parameters like mean and standard deviation (SD)]; and, b) correlation between the distance of the available landmark(s) from the facial nerve trunk and the volume of the benign mass lesion [expressed by Pearson correlation coefficient (r)].

The entire surgical procedure was carried under aided vision, using a binocular surgical loupe (Carl Zeiss EyeMag Smart; Carl Zeiss Meditec AG; Jena, Germany) with 2.5x magnification and fixed focusing distance. Measurements were carried out with sterile graduated metallic scales and spring callipers. 
Superficial or partial superficial parotidectomy was performed using the standard cervico-parotido-facial incision [Figure $1 \mathrm{~A}$ ]. The surgical landmarks attempted to disclose during the anterograde dissection of the facial nerve were the tragal pointer (TP), posterior belly of digastric muscle (PBDM), tympanomastoid suture line (TMS), and the stylomastoid artery (SMA) [Figure 1B,C]. However, in a given patient, it was not always possible to expose all four owing to the nature and size of the mass lesion. Also, SMA could be detected in only a few patients (vide infra; Results). Therefore, at least two identifiers among TP, PBDM and TMS were successfully searched for; otherwise, such patients were excluded from the study. Volume [in cubic centimeter (cc)] of the benign mass lesions were obtained prior to surgery through ultrasonography (USG). Distance of the revealed landmarks from the facial nerve trunk were measured using spring callipers [Figure 1D] and graduated scale. The two sets of values

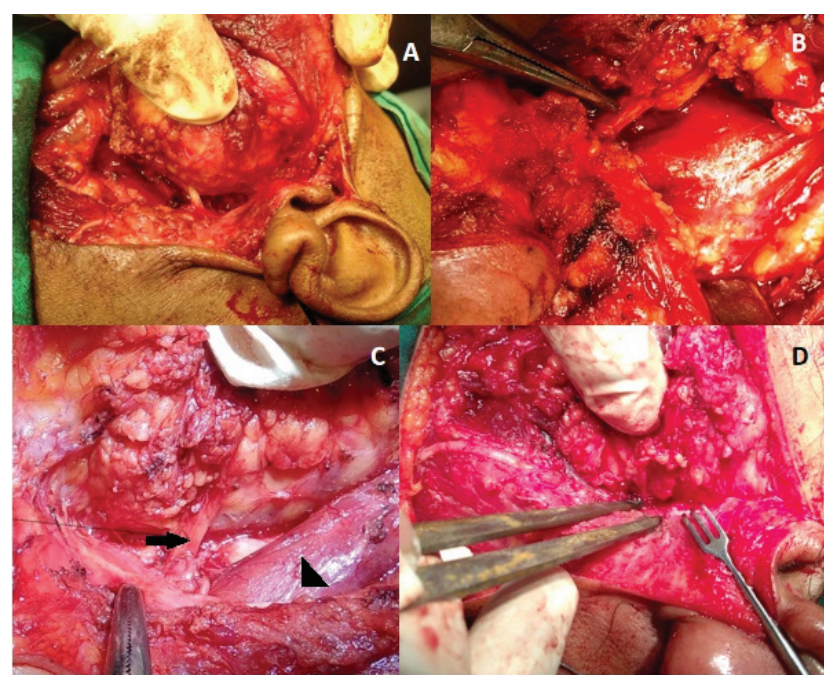

Figure 1. Per-operative photographs obtained during superficial parotidectomy. A: Left parotid mass with main facial nerve trunk exposed through the standard cervicoparotido-facial incision. B: Right-sided facial nerve main trunk along with overlying stylomastoid artery, with a hemostatic forceps inserted in between. C: Right-sided facial nerve main trunk with overlying stylomastoid artery (arrow), tragal pointer (shown by hemostatic forceps) and posterior belly of digastric muscle (arrowhead). D: Intraoperative measurement of distance between right-sided facial nerve main trunk and tympanomastoid suture line being taken using spring callipers.
- volume of the mass lesion, and distance of the facial nerve trunk from the exposed landmarks were correlated to find out how the former influenced the landmark-based dissection of the facial nerve trunk.

As the necessary component of pre-operative work-up, all the patients were subjected to USG of the parotid regions. Occasionally, magnetic resonance imaging (MRI) was advised to obtain further details regarding the texture and composition of the parotid mass lesions. However, data for volumetric assessment were obtained from the USG parameters only. The median values of the three axes in their greatest dimension, namely the antero-posterior length, depth and craniocaudal height of the mass lesions were obtained through USG (GE Healthcare; LOGIQ ${ }^{\text {TM }}$ E9 $X_{\text {Dclear }}^{\mathrm{TM}} 2.0$ ultrasound system; Chicago, Illinois, USA; in Volume Navigation 3D GPS Markers C1-6VN-D protocol). The volume was subsequently calculated for each benign mass lesion under consideration.

All the surgeries were performed by the same group of surgeons. Each surgeon in the group had a minimum of 10 years of experience in performing head-neck surgeries. Written informed consent was obtained from each patient at the time of his/her inclusion in the study. The study obtained clearance from the Institutional Ethical Committee (MC/Kol/IEC/Non-spon/661/11 2017). All investigations and interventions were carried out maintaining the standard protocol of ethical principles for medical research involving human subjects laid down by the Declaration of Helsinki, 1964, and its subsequent modifications.

\section{Statistical analysis}

Data were compiled in several Windows Excel spreadsheets (Microsoft Corporation; Redmond, Washington, USA) and evaluated thereafter by SPSS (Statistical Package for Social Sciences) 
S. Sardar et al., Do Benign Mass Lesions in the Superficial Lobe of Parotid Gland Influence Landmark-Based Search for Facial Nerve Trunk At Surgery?

Software version 20.0 (IBM Corporation; Armonk, New York, USA). Appropriate statistical parameters like mean, SD, and Pearson's correlation coefficient $(r)$ were used to interpret the results. P values $<0.05$ were considered statistically significant.

A level of evidence of $2 \mathrm{~b}$ has been assigned to this study, following guidelines provided by the Oxford Centre of Evidence-based Medicine ${ }^{5}$.

\section{RESULTS}

A total of 32 patients met the selection criteria and were included in the study. The average age was 39 years (range: $18-70$ years), the peak being in the third decade $(\sim 44 \%)$ and followed by the fourth $(\sim 22 \%)$. There was a marginal female predilection (female:male=1.29). The tail of the parotid was most commonly involved $(50 \%)$, followed by pretragal region (34.3\%). The benign parotid mass lesions mostly included neoplasms (75\%), the rest being various cysts and hamartomas. Among the neoplasms, pleomorphic adenoma $(\sim 66 \%)$ and Warthin's tumor ( 9\%) were the commonest ones (Table 1).

Table 1. The different benign parotid mass lesions as evident on histopathology $(n=32)$.

\begin{tabular}{ll}
\hline Diagnosis from histopathology* & Number (\%) \\
\hline Pleomorphic adenoma & $21(65.6)$ \\
Warthin's tumor\# & $03(9.4)$ \\
Benign cyst, unclassified & $03(9.4)$ \\
Benign lympho-epithelial cyst & $02(6.25)$ \\
Hemangioma\# & $02(6.25)$ \\
Epidermal cyst & $01(3.13)$ \\
\hline
\end{tabular}

${ }^{*}=$ in conditions where lesions could affect both parotid glands (\#), any one side of involvement was considered for surgery at a time and was included in the study accordingly

TP was the most easily available landmark and was identified in all patients. PBDM and TMS could be exposed in 26 and 25 patients, respectively (Figure 2). In only three instances, SMA could be identified, positioned just above the facial nerve trunk. All four landmarks were identi-

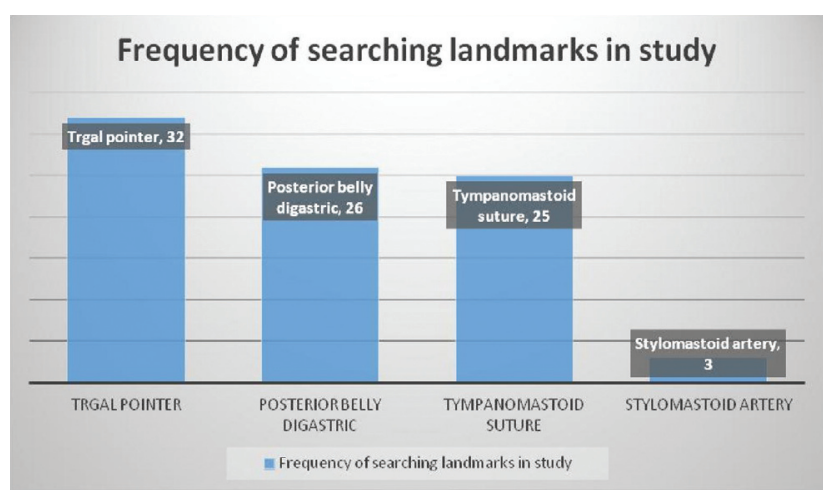

Figure 2. Frequency of successful identification of landmarks for facial nerve main trunk during superficial parotidectomy $(\mathbf{n}=32)$.

fied in only one patient. Average distances between the facial nerve trunk and its landmarks, namely, TP, PBDM, and TMS were $12.79 \pm 2.33$ $\mathrm{mm}, 9.78 \pm 1.21 \mathrm{~mm}$ and $7.58 \pm 1.33 \mathrm{~mm}$, respectively.

The mean volume of the benign mass lesions in the superficial lobe of parotid was $9.7 \mathrm{ml}$ (range: 6.2-20 ml). Pearson correlation coefficients between the volume of the benign mass lesions in the superficial lobe of parotid and the distance of the facial nerve trunk from the exposed surgical landmark were -0.11 ( $\mathrm{P}=0.549), 0.04$ ( $\mathrm{P}=0.846)$ and $-0.16(\mathrm{P}=0.445)$ for TP, PBDM and TMS, respectively (Figure 3). Thus, the PBDM was the only landmark whose distance from the facial

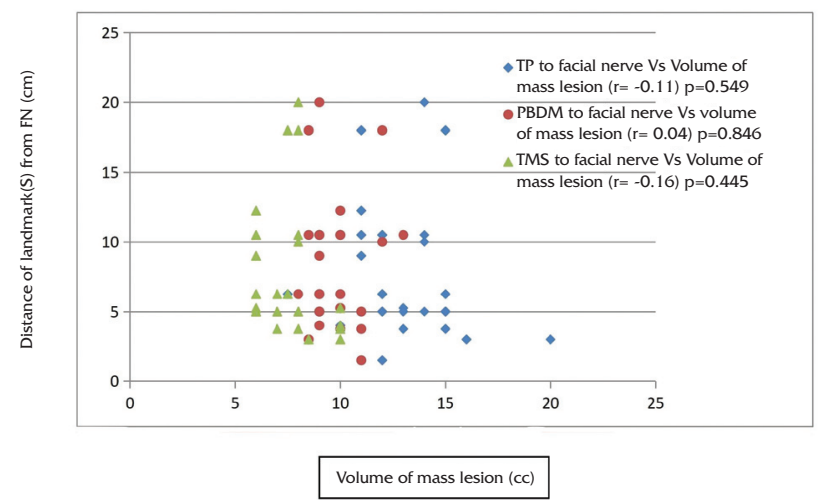

Figure 3. Scatter plot diagram depicting the relationship between tumor volume and the distance of the facial nerve trunk from a given landmark $(n=32)$. [TP = tragal pointer; $\mathbf{P B D M}=$ posterior belly of digastric muscle; TMS = tympanomastoid suture; $F N$ = facial nerve main trunk; $\mathbf{r}=$ correlation coefficient]. 
nerve trunk maintained a positive correlation. And, although not statistically significant, PBDM maintained the strongest association with the volume of the parotid mass lesion on relative grounds. Therefore, in this study population, PBDM was found to be the most consistent and the least variable landmark both from the perspectives of the distance from the facial nerve trunk and also in the presence of a benign mass lesion in the superficial lobe of parotid.

\section{DISCUSSION}

The present study has dealt with some revealing intra-operative findings regarding the variations of the anatomic identifiers of facial nerve trunk in the setting of histologically proven benign mass lesions involving the superficial lobe of parotid gland, and how the volume of such lesions affected the relationship between these landmarks with the facial nerve. The context finds its relevance in the fact that surgeons often encounter difficulties in locating the facial nerve trunk with respect to its landmarks in situations where their relationship is unpredictably distorted by the variable volumes of the mass lesions occupying the superficial lobe of the parotid.

This study excluded the malignant tumors because they tend to involve/invade the facial nerve trunk and its branches along with the surrounding extra-glandular tissues, violate natural tissue planes thereby making dissection cumbersome, cause irregular and uneven distortion of the nerve trunk thus making landmark-based dissection relatively difficult, and also because they often extend to the deep lobe and commonly result in facial paresis of varying grades at presentation. In such conditions, the true effect of the volume of the mass lesions on the relative positions of anatomic locators with respect to the facial nerve trunk would not be possible to assess properly. Benign mass lesions which should keep the facial nerve free from involvement thus would serve as an ideal surgical model to study the resultant variations secondary to the pathology.

The anatomic landmarks chosen in this study for facial nerve identification during superficial or partial superficial parotidectomy were TP, PBDM, TMS and SMA, although the first three were actually used to measure the distance from the facial nerve trunk. We found that TP, a deep cartilaginous landmark $1 \mathrm{~cm}$ superior and superficial to the nerve, as the commonest and the most easily sorted landmark identified in all patients. However, it showed the most variable relationship in terms of linear distance with facial nerve $(S D=2.33 \mathrm{~mm})$. SMA was the least consistent landmark and found only in three patients, usually along the facial nerve main trunk. Thus, it could not be relied upon as a good identifier for the nerve. PBDM, arising from the digastric ridge just below stylomastoid foramen, was identified in $81 \%$ of the patient cohort in our study. It was the most consistent landmark in our observation and also the least variable $(\mathrm{SD}=1.21 ; \mathrm{r}=0.04)$. It has been found to stay in the same depth of the distal part of the facial nerve, parallel and below the main trunk. Our findings corroborate with those suggested in the existing literature ${ }^{6}$. TMS, a landmark palpable as a hard ridge deep to the cartilaginous portion of external auditory canal, although having the least average distance $(7.58 \mathrm{~mm})$ from facial nerve trunk, was found next to PBDM in overall consistency and variability in this study (identified in 78\%; $\mathrm{SD}=1.33 ; \mathrm{r}=0.16$ ).

Various authors in their studies criticized TP as a reliable landmark since it is cartilaginous, mobile, asymmetric, and has a blunt tip. Pather and Osman ${ }^{7}$ demonstrated that facial nerve trunk was found at 24.3-49.2 $\mathrm{mm}$ from the TP and 9.7-24.3 $\mathrm{mm}$ from PBDM. Rea et al. ${ }^{8}$ in their study with cadavers found the main trunk of the facial nerve to be at $6.9 \pm 1.8 \mathrm{~mm}$ from the TP, $5.5 \pm 2.1 \mathrm{~mm}$ from PBDM, and $2.5 \pm 0.4 \mathrm{~mm}$ from TMS. Witt et al. ${ }^{9}$ stated that TMS is a significantly closer and 
less variable anatomic landmark compared with PBDM both in cadavers and in live patients. De Ru Ja et al. ${ }^{10}$ in 2001 concluded that the anatomic landmark with the best yield, having the facial nerve trunk within the range of $3 \mathrm{~mm}$, was the TMS. In 1997, Beahrs ${ }^{11}$ showed that bony structures were more suitable as anatomic guides because of their rigid and reliable locations. The styloid process and the TMS had been described as reliable anatomic landmarks in their study. Consequently, PBDM and TMS are to be relied upon as the more constant landmarks compared to TP or SMA, and our findings do find support from the data provided by various studies in the literature and annals on this topic.

The literature is deplete with studies that specifically dealt with the relationship between distance of the surgical landmark from the facial nerve trunk with the volume of benign mass lesions involving the parotid gland. Maddalozzo et al. ${ }^{12}$ in a recent study (2019) have shown that deep lobe lesions can significantly alter the course of the extratemporal facial nerve, laterally displacing the trunk and pes anserinus to a more superficial location. Such distortion makes landmark-based identification of the main trunk of the facial nerve less accurate. In an earlier study dating back to 1971, Becker and Tabb ${ }^{13}$ had already pointed out that deep lobe parotid tumors could push the facial nerve trunk at a much superficial plane, immediately distal to its exit from the stylomastoid foramen. However, no such attempt has been made to date that would consider benign mass lesions involving exclusively the superficial lobe of the parotid. The present study reveals that the relationship between the volume of the benign mass lesions in the superficial lobe of parotid maintained a close association with the distance of a given surgical landmark from the facial nerve trunk. There was a strong correlation between the two parameters, the strongest being in case of PBDM. That TP and TMS maintained a strong albeit negative correlation could be explained by the fact that they were rigid structures with limited or least chance of being displaced and had their distances from the facial nerve trunk decreased with increase in the volume of benign mass lesion in the superficial lobe of the parotid. The opposite was noticed in case of PBDM due to its relative malleability.

Reproducibility of the results obtained in our study seems promising because the methodology carried out is simple and can be easily repeated. We obtained the pre-operative volumetric data from conventional imaging, and the peroperative measurements were basic and fundamental, with easily available tools. However, another important factor that could influence the outcome was the position of benign mass lesions in the superficial lobe of parotid. Interestingly, distribution of the lesions as we observed in our cohort was comparable with the available data in the relevant literature ${ }^{6}$. Tail of the parotid was the commonest site for the benign mass lesions in this study (16 patients; $50 \%$ ), followed by the pre-tragal region (11 patients; 34.3\%). The differential location of the mass lesions in the parotid might influence the extratemporal course of facial nerve in different ways. Lesions in the pretragal location would affect the course of the facial nerve trunk, while those in the parotid tail appear more prone to alter the course of the cervico-facial branch. However, the present study maintained a homogeneous approach in this aspect and considered potential deviation of the course of main trunk of the facial nerve and its relationship with the anatomic identifiers as the sole objective. Thus, while a mass lesion in the pre-tragal region would alter the course of the facial nerve trunk with respect to the TP and SMA, the same in the parotid tail region could influence the course of the facial nerve trunk with respect to PBDM and TMS. Therefore, it is evident that both the volume of the mass lesions and their position in the parotid gland play important roles in determining the relationship between the facial nerve 
main trunk and its anatomic identifiers.

Our study had few limitations. First, the number of patients could be increased to strengthen the reliability of the results. However, the trend could be well-appreciated with the representative sample size we had, and the results from this tertiary-care teaching set-up could be extrapolated to a larger study cohort with predictable outcomes.

Secondly, the present study did not take into consideration the normal anatomic variation of the relationship of the facial nerve trunk with its surgical landmarks as a reference standard. However, it needs to be emphasized that the values obtained in this study and their standard deviations calculated were absolute and independent of any reference standard. This is more so because the given geo-anthropometric factors that would have influenced the reference standard, being common variables, would have also determined the outcome of the present study as well. Our objective in this study was to provide the surgeons with some idea about the effects of differential volumes of benign mass lesions in the superficial lobe of parotid could have on the distance between the facial nerve trunk and its surgical landmarks, with the presumption that the normal anatomic variation in health would not influence the outcome of our study significantly.

Thirdly, outcomes from the present study could be compared with those from some pre-existing datasets regarding the nature and position of the benign mass lesions in the parotid, but we could not compare the volumetric data of such lesions and their effects over the anatomic locators of the facial nerve trunk. However, we consider this as a strength of our study because this is the first attempt of its kind where volumetric data of benign mass lesions were utilized for the purpose, and the specific outcomes could set a pio- neering example to follow for future studies of similar pattern and objectives.

\section{CONCLUSION}

In the present series of 32 patients with benign mass lesions in the superficial lobe of parotid, pleomorphic salivary adenoma followed by Warthin's tumor were the most common neoplasms, succeeded by cystic lesions and hemangiomas. TP was the most easily available landmark on dissection, while PBDM was the most consistent and the least variable one with respect to the distance from the facial nerve trunk when the volumetric data of benign mass lesions in the superficial lobe of parotid were considered as the factors influencing the distance.

\section{REFERENCES}

1. Kochhar A, Larian B, Azizzadeh B. Facial nerve and parotid gland anatomy. Otolaryngol Clin North Am. 2016;49:273-84. [CrossRef]

2. Kwak HH, Park HD, Youn $\mathrm{KH}$, et al. Branching patterns of the facial nerve and its communication with the auriculotemporal nerve. Surg Radiol Anat. 2004;26:494-500. [CrossRef]

3. Bittar RF, Ferraro HP, Ribas MH, Lehn CN. Facial paralysis after superficial parotidectomy: analysis of possible predictors of this complication. Braz J Otorhinolaryngol. 2016;82:447-51. [CrossRef]

4. Thielker J, Grosheva M, Ihrler S, Wittig A, GuntinasLichius O. Contemporary management of benign and malignant parotid tumors. Front Surg. 2018;5:39. [CrossRef]

5. Oxford Centre for Evidence-Based Medicine. Levels of Evidence (March 2009) [cited 2020 Jan 11]. Available from: https://www.cebm.net/2009/06/oxford-centreevidence-based-medicine-levels-evidence-march-2009/

6. Watkinson J, Gilbert R. Stell \& Maran's Textbook of Head and Neck Surgery and Oncology. Watkinson J, Gilbert R, editors. 5th ed. London: CRC Press; 2011. p. 714-7. [CrossRef]

7. Pather N, Osman M. Landmarks of the facial nerve: implications for parotidectomy. Surg Radiol Anat. 2006;28:170-5. [CrossRef]

8. Rea PM, McGarry G, Shaw-Dunn J. The precision of four commonly used surgical landmarks for locating the facial nerve in anterograde parotidectomy in humans. Ann Anat. 2010;192:27-32. [CrossRef]

9. Witt RL. Facial nerve function after partial superficial parotidectomy: an 11-year review (1987-1997). Otolaryngol Head Neck Surg. 1999;121:210-3. 
S. Sardar et al., Do Benign Mass Lesions in the Superficial Lobe of Parotid Gland Influence Landmark-Based Search for Facial Nerve Trunk At Surgery?

\section{[CrossRef]}

10. de Ru JA, van Benthem PP, Bleys RL, Lubsen H, Hordijk GJ. Landmarks for parotid gland surgery. J Otolaryngol Otol. 2001;115:122-5. [CrossRef]

11. Beahrs $\mathrm{OH}$. The surgical anatomy and technique of parotidectomy. Surg Clin North Am. 1977;57:477-93. [CrossRef]
12. Maddalozzo J, Johnston DR, Isaac A, Bhushan B, Rastatter JC. Displacement of the facial nerve by deep parotid lobe lesions in the pediatric population. Laryngoscope Investig Otolaryngol. 2019;4:550-3. [CrossRef]

13. Becker FF, Tabb HG. Bilateral benign mixed tumor of the deep lobe of the parotid gland. Arch Otolaryngol. 1971;94:158-61. [CrossRef] 